\title{
THE TRIPLE WAY
}

SAINT BONAVENTURE

A new adaptation of the great Doctor's mystic philosophy. Critics have said: "A golden little book ... translation excellent, even brilliant." Catholic Review Service. "Ideal for meditative reading when moments are precious and much of value has to be compressed into a short time." Naomi Gilpatrick. "This is a work not only of meditation but a plan of imitation of Christ." NCCW Message. 86 pp., $\$ 1.50$.

Your bookstore or Dept. 4-2487

\section{ST. ANTHONY GUILD PRESS}

Paterson 3, N. J.

\section{REVISTA INTERAMERICANA DE BIBLIOGRAFIA INTER-AMERICAN REVIEW OF BIBLIOGRAPHY}

A documentary triannual containing articles, book reviews, notes and selected bibliographies pertaining to Latin America. A staff of correspondents in forty-two nations and territories provides news reports about authors, books, periodicals, publishers and libraries.

Javier Malagón

Editor

José E. Vargas Salas Assistant Editor

Published by the Division of Philosophy, Letters and Sciences,

Department of Cultural Affairs, Pan American Union, Washington 6, D. C.

Subscription rates: $\$ 3.00$ a year in the Americas and Spain; $\$ 3.50$ in all other countries. 


\section{Saint Bernardine of Siena College Conducted by}

The Franciscan Fathers

$$
\text { of the }
$$

Province of the Most Holy Name of Jesus

A Liberal Arts College Offering Courses Leading to Degrees in Arts, Science and Business. Tuition $\$ 12.50$ Per Credit Hour.

Address: Dean of Admissions

Loudonville, New York

\section{ARCHIVO IBERO-AMERICANO}

\section{A Quarterly Review of Historical Studies}

Published Since 1914 by

The Franciscan Fathers of Spain

Annual Subscription $\ldots \ldots \ldots \ldots \ldots \ldots \ldots \ldots . . \ldots$

Single Copy $\ldots \ldots \ldots \ldots \ldots \ldots \ldots \ldots \ldots \ldots \ldots \ldots$

Complete File, Second Series (1941-) . . . . . . . \$60.00

JoAquín Costa, 36

Madrid 2, SpaIN 